\title{
THE ROLE OF NATIONAL CULTURES IN SHAPING THE CORPORATE MANAGEMENT CULTURES: A FOUR COUNTRIES THEORETICAL ANALYSIS
}

\author{
Mohammad Ayub Khan \\ Tecnologico de Monterrey, Mexico \\ Ekaterina Panarina \\ Perm National Research Polytechnic University, Russia \\ Tecnologico de Monterrey, Mexico
}

\begin{abstract}
This paper studies the impact of national cultures on the management cultures of organizations. In doing so, this paper explores the differences and similarities among the national cultures of USA, Mexico, Pakistan and Russia, and subsequently analyzes the impacts of such differences and similarities on the management cultures of organizations in these countries. The findings of this study suggest that cross cultural differences greatly influence the management culture in organizations. This finding presents cross cultural management challenges for organizations in these countries in order to build multinational long-term strategic business partnerships.
\end{abstract}

Keywords: Corporate culture, Cross cultural management, Management style, National culture, The role of national culture, Cultural distance.

DOI: http://dx.doi.org/10.15549/jeecar.v4i1.152

\section{INTRODUCTION}

The role of culture in influencing international business management practices and approaches is an undisputed fact (Alvesson, 2002; $\mathrm{Au}$, 1999). Studies have shown that national cultural systems as well as individual cultures greatly impact the corporate cultural system (Tayeb, 1995; Kroeber and Kluckhohn, 1985) in many ways. For example, national culture influences managerial decision-making, leadership styles and human resource management practices (Li, Lam and Qian, 2001; Willmott, 2000). Similarly, national cultures affect managerial functions such as communication, motivation, organizational design, people's expectations of work design, and reward systems (Nicholls, Lane and Brechu, 1999). Moreover, organizational polices (e.g., human resource polices) are influenced by various national institutions such as labor laws, educational and vocational training practices, and industrial standards and regulations (Budhwar, 2001). Culture organizes values into mental programs and the behavior of people within organizations is an enactment of such programs (Hofstede, 1980).

Organizational culture refers to the beliefs and values that have existed in an organization for a 
long time, and to the beliefs of the staff and the foreseen value of their work that will influence their attitudes and behavior. The culture within an organization is very important, playing a significant role in whether it is a happy and healthy environment in which to work. In communicating and promoting the organizational ethos to employees, their acknowledgement and acceptance of it can influence their work behavior and attitudes. When the interaction between the leadership and employees is good, the latter will make a greater contribution to team communication and collaboration, and will also be encouraged to accomplish the mission and objectives assigned by the organization, thereby enhancing job satisfaction (Tsai, 2011).

Organizations can be the same in such objective dimensions as physical plant, layout or product, yet totally different in the meanings which the surrounding human cultures read into them (Trompenaars and Turner, 1998). Organizational culture is shaped not only by technologies and markets, but by the cultural preferences of leaders and employees, and national culture has a strong impact on people's interpretations, understandings, and assessment of those with whom they work. Cultural values are important for interpersonal trust, team work and the role of women in the workplace, among other issues (Greer and Stephens, 1996; Stephens and Greer, 1995). Cultural differences play a significant role in the way people conduct their lives and behave on the job. Culture is the interactive aggregate of common characteristics that influence a human group's response to its environment (Hofstede, 1997). Cultural differences, if not understood and appreciated well, can lead to failures in business and social life (Ghemawat and Reiche, 2011). Several studies (e.g., Khilji, 2003) have been conducted on the importance of learning about national cultures and the impact of national cultures on the operations of organizations. However, there are no studies on the issue of organizational cultural differences and similarities between USA, Mexico, Pakistan and Russia. That being the case, there is a dearth of literature on this subject and this paper attempts to address this issue. This paper intends to answer the following questions:

1. Are the national cultures of USA, Mexico, Pakistan and Russia same or different?

2. How national cultures influence the management cultures of organizations?

3. Are there differences and similarities between the management cultures of organizations of the four countries under study?

4. What if there are differences and similarities between the management cultures of organizations of USA, Mexico, Pakistan and Russia?

These four countries were chosen specifically as they represent four contrasting national cultures, that are influenced by different history, traditions, attitudes, etc. that make them bright examples of Eastern -Western, South-North concepts. We want to review how the different national cultures shape the organizational climate and environment to successful leadership, team work and work results. A key question involves how culture affects behavior around the world and these four countries make a significant impact on global distribution of power and economic and political changes. It's important to notice that characterizations of "national" cultures are not to be understood as meaning to stereotype any nation or its citizens, but to be a shorthand representation of particular clusters of outlooks and expectations.

\section{LITERATURE REVIEW}

To answer the questions above, this paper (1) Explains the national culture and its scope, (2) Analyzes the cultures of Pakistan, Mexico, Russia and the USA, (3) Explains management culture of organizations (4) Compares and contrasts the management cultures of organizations of Pakistan, Mexico, Russia and the USA. The literature review focuses on the role of national cultural variables in influencing the management cultures of organizations as shown in Figure 1: 


\section{National culture}

- Religion

- Social organization

- Language

- Time concept

- Power distance

- Collectivist-individualistic

- Masculinity-femininity

- Uncertainty avoidance

\section{Corporate management culture}

- General management style

- Decision making

- Staffing

- Controlling

- Time management

- Employee motivation

- Role of religion in the workplace

Figure 1. National Cultures Influence the Management Cultures of Organizations.

\section{Culture: Concept and Scope}

The role of national cultures in shaping organizational work environment and other social institutions has been studied by several researchers in the field (i.e., Tayeb (1994; Zawawi, 2008; Titiev, 1958). Culture is all that which we share with other members of our nation, region, or group but not with members of other nations, regions, or groups (Hofstede, 1983). Culture encompasses values which are shared between people within a social set up with specific nationality or country of origin (Anwar and Chaker, 2003). "Culture is created, acquired, and/or learned, developed and passed on by a group of people, consciously or unconsciously, to subsequent generations. It includes everything that a group thinks, says, does, and makes - its customs, ideas, mores, habits, traditions, language, and shared systems of attitudes and feelings- that help to create standards for people to co-exist" (Rijamampianina 1996, p.124). Culture is also considered as an independent environmental variable specific to one specific country (Nicolaidis, 1991). Furthermore, "Culture is the programming of the mind, which distinguishes the members of one human group to another. Being more precise, culture is a pattern of basic assumptions - invented, discovered, or developed by a given group as it learns to cope with its problems of external adaptation and internal integration" (Hofstede, 1980). Culture is embedded in everything what we do, what we have and what we think. Culture is learned through membership in a group and is composed of set of values, assumptions and beliefs and that influence the attitudes and behaviors of group members (Ghemawat and Reiche, 2011). In fact, culture, is a set of distinctive spiritual, material, intellectual and emotional features of society or a social group; it encompasses art and literature, lifestyles, ways of living, value systems, traditions and beliefs (UNESCO, 2002).

As we can see "culture" has been defined in number of ways. There is no consensus among sociologists and anthropologists regarding the definition of culture. One of the most comprehensive definitions of the term culture was provided by the British anthropologist Edward Tylor. He defined culture as "that complex whole which includes knowledge, belief, art, morals, law, custom and any other capabilities and habits acquired by man as a member of society" (Taylor, 1884).

Culture provides a guide or the directions for how its citizens think and behave, then cultural values influence business environment by being identified to develop a shared understanding of what the organization stands for, including ethical behaviour and social responsibility.

\section{Understanding the National Cultural System}

The national cultural system is made of values, beliefs and is the collective programming of mind (Nicholls, Lane and Brechu, 1999). The national cultural system is also defined as "a set of historically evolved, learned and shared values, attitudes and means. The term nation refers to culture, social, economic and political institutions influence how organizations are managed in different environments" (Tayeb, 1994). To analyze and understand national cultural systems, cultures can be classified into distinct levels: individual; group; organizational; industrial, national and geographic regions (Ghemawat and Reiche, 
2011). Cultures are also grouped based on inner elements (i.e., history, beliefs, values and work view), cultural activities (i.e., roles, art, communication patterns, rules, customs, technology and material culture), and cultural systems (i.e., religion, economic, law, education, social organization, family, health and politics) (Dodd, 1998; Gannon, 1980; Gannon and Associates, 1994). Over the past several years different authors (as shown in Table-1) have used different dimensions to analyze and classify national cultures systems:

Table 1. Classification of National Cultures

\begin{tabular}{|l|l|}
\hline \multicolumn{1}{|c|}{ Authors/Years } & \multicolumn{1}{c|}{ National Cultural Dimensions } \\
\hline $\begin{array}{l}\text { Kluckhohn and Strodtbeck } \\
(1961)\end{array}$ & $\begin{array}{l}\text { Human nature orientation; Man-nature orientation; Time } \\
\text { orientation; Activity orientation; Relational. }\end{array}$ \\
\hline Parsons and Shills (1962) & $\begin{array}{l}\text { Affectivity-affective neutrality; Self-orientation- collectivity- } \\
\text { orientation; Universalism-particularism; } \\
\text { Ascription-achievement; Specificity - diffuseness. }\end{array}$ \\
\hline Hofstede (1980; 2001) & $\begin{array}{l}\text { Power distance; Individualism/collectivism; } \\
\text { Masculinity/femininity; Uncertainty avoidance; Long-term/ short- } \\
\text { term. }\end{array}$ \\
\hline Schwartz (1992; 1999) & $\begin{array}{l}\text { Conservatism versus autonomy; Hierarchy versus egalitarianism; } \\
\text { Mastery versus harmony. }\end{array}$ \\
\hline $\begin{array}{l}\text { Trompenaars and } \\
\text { Hampden-Turner (1997) }\end{array}$ & $\begin{array}{l}\text { Universalism versus particularism; Individualism versus } \\
\text { communitarianism; Specific versus diffuse; Neutral versus } \\
\text { emotional; Achievement versus ascription; Sequential time versus } \\
\text { synchronous time; Internal direction versus outer direction. }\end{array}$ \\
\hline $\begin{array}{l}\text { House, R.J., Hanges, P.J., } \\
\text { Javidan, M., Dorfman, P. and } \\
\text { Gupta, V.(2004) }\end{array}$ & $\begin{array}{l}\text { Power distance; Uncertainty avoidance; Assertiveness; Institutional } \\
\text { collectivism; In-group collectivism; Future orientation; } \\
\text { Performance orientation; Humane orientation; Gender } \\
\text { egalitarianism. }\end{array}$ \\
\hline
\end{tabular}

Since in this paper, some of the dimensions of national culture proposed by Hofstede (1980; 2001) are being studied, therefore, the five dimensions of national cultures of Hofstede (2001) are briefly explained in the following:

1. Power distance: The degree of equality, or inequality between people in a society.

2. Individualism vs. collectivism: The degree to which people of a society understand themselves as individuals, as apart from their group.

3. Masculinity vs. femininity: the degree the society reinforces or not the traditional masculine work role model.

4. Uncertainty avoidance: The degree to which people in a society feel uncomfortable in unexpected, surprising and unknown situations.

5. Long-term vs. short-term orientation: The degree people attach importance to a future oriented way of thinking rather than to a short-term oriented one.

We decided to work on the Hofstede's dimensions of national cultures because these dimensions provide us understanding of single national cultures as well as allow us to compare and contrast different national cultures at the same time. These dimensions provide a holistic and simple way of understanding of the national cultures involved in the study. Additionally, Hofstede dimensions of national cultures are widely used and cited in most of the scientific research outlets. Hofstede's theories have influenced both academics and practitioners alike as much as his critics acknowledge his works even though they do not agree with his theory and conclusions (Bing, 2014).

Most of the studies undertaken on differences in national cultures and the impact of such differences on organizations find national cultures having profound effects on leadership 
style, communication, motivation, organizational design, people's expectations of work design, and rewards in organizations (Nicholas et al., 1999). Though national and organizational cultures are different in that that national cultural differences reside mostly in values and less in practices whereas organizational cultural differences reside in practices, less in value (Hofstede, 1997; Hofstede, 1980; Hofstede, 2007) they are interdependent and by that it means that national cultures influence directly or indirectly organizational cultures and vice versa. The national cultural identity is considered fundamental for individual characteristics such as self-esteem, functional effectiveness, mental health and quality of life (UNESCO, 2002) and thus have direct effects on the managerial styles within organizations.

\section{The National Cultural Variables}

The national cultural system is composed of diverse variables including language, religion, rules and regulations, political system, social organization, history, economy, technology, education, values, attitudes, customs, traditions, concept of time, music, art, and architecture, for instance. Notwithstanding, in this paper, a few of these variables are being studied to compare the national cultural systems of the four countries under study.

Religion: Religion plays the role of a foundation stone in every aspect of human life (Balan and Vreja, 2013). About the role of religion in one's professional life, Weber (2004) suggests that for example, the Protestants work ethic (U.S. cultural aspect) promotes hard working, saving money and managing time well and therefore, leisure activities (going to bar, nightclubs, gambling) are not well seen (Furnham, 1990). Furthermore, working is a way to receive God's blessing and mercy and therefore, working is viewed as the most important obligation in one's life (Weber, 2004). Work is believed to contribute to the overall well-being of the individual and society around (Banks, 1998). The influence of religion is also found in building positive attitude towards work, organizational commitment, and job quality. Protestantism emphasizes hard-work, individual achievement, and a sense that people can control their environment (Weber, 2004; Banks, 1998). Similarly, the religion of Islam (Pakistanis' cultural aspect) places great importance on the role of work and working in one's life. Time should not be wasted and planning is important to achieve satisfactory results. Islamic messages and guidance vehemently support contributing to the development of the world. In Islam, work is given special importance to the extent that it is considered as an act of worship itself (Hassan, 1988; Ahmad and Owoyemi, 2012). Therefore, Islam lays a lot of emphasis on work and the need for man to work for earning his livelihood to be independent, self-sufficient and to uphold his dignity among his peers and in his community/society. Employees should fulfill their jobs for the societal obligation with the purpose to seek pleasure of Allah. Muslim must perform his duty as a religious obligation, and a motivational reward is not only linked with earthly reward but also awarded in the hereafter (Hassan, 1988; Ahmad and Owoyemi, 2012). Employees must adhere to diligence and efficiency as well as fairness in preserving public interest.

Religion is a system of common beliefs or attitudes concerning a being or a system of thought that people consider to be sacred, divine, or the highest truth. Religion also incorporates the moral codes, values, institutions, traditions, and rituals associated with this system. Religion influences culture and therefore business and consumer behavior, in several ways (Hassan, 1988; Ahmad and Owoyemi, 2012; Weber, 2004; Banks, 1998).

Social Organization: Social organization is another key element of nation cultural system. Diverse cultures have different social systems or system to organize the society around: family systems, neighborhood, ethnic groupings, and tribal systems for instances (Georgas, 2003). The social organization is also about how these variables (of social organizations within each cultural system) are defined and interpreted. For example, family may include your immediate or direct relatives including your wife/husband and children (which is also called a nuclear family system) in one culture (U.S cultural aspect); and your wife/husband, children, parents, uncles, and cousins etc. are in other cultures (which is considered extended or traditional family system, Mexican and Russian, Pakistani cultural aspect). Whether nuclear or extended, the family is a social group characterized by common residence, economic cooperation, and reproduction (Georgas, 2003; Brown, 1973; Ouchi and Jaeger, 1978). Social 
organizations as a national cultural component also include aspects of ethnicities, classification based on economics, family trees, distribution of roles and responsibilities among gender (male and female); and social hierarchies so and so forth (Georgas, 2003).

Language: The role of language as a national cultural component is undebatable in the field of international business and management. It is not only important for business or management communication but also and most importantly it shows the insight of a culture. Learning the language of the host country helps understanding the cultural sensitivities of the local employees and managers (Hooker, 2008; Hall, 1976). Language has both verbal (words) and nonverbal (facial expressions and gestures) characteristics. Languages are also classified as high and low context (Hooker, 2008). Low context language speakers (U.S. cultural aspect) focus on the words, message and the content when communicating whereas the high context language speakers (Mexican and Pakistani cultural aspect) focus more on the context, surroundings and how the words are communicated. Low context language speakers tend to depend on the clarity of the message, written documents, preciseness and information-rich document. As a result, speakers must rely more heavily on providing greater message clarity, as well as other guarantees like written documents and information-rich advertising. High context communicators generally look for long term personal relationships, mutual trust and personal prestige (Hall, 1976). In high-context communication, the message cannot be understood without a great deal of background information. Low-context communication spells out more of the information explicitly in the message (Hooker, 2008). In low-context cultures, context is less important; most information is explicitly spelled out (Hall, 1976). The role of language is fundamental for conversations, establishing and managing interpersonal affairs, managing organizations beyond the national borders and leading multinational agreements and relationships (Steers, Sanchez-Runde and Nardon, 2010). Our histories, traditions, and knowledge are preserved and disseminated through language. Language and linguistic structures are culture centered which means while the culture supplies the meaning and meaning-making mechanisms, language in itself provides the symbols to support the delivery of such meanings to the intended audience or target (Steers, Sanchez-Runde and Nardon, 2010). In nutshell, language reflects the culture in that it presents ideas, thoughts and artifacts and is a channel of sharing information, knowledge, values, experiences and thoughts (Steers, Sanchez-Runde and Nardon, 2010).

Time Concept: This element of the national cultural system describes how individuals in a particular cultural group approach management of time. Time concept includes feeling, perception and use of time. Time is controlled either by the nature or individuals. Time is money (U.S cultural aspect, Russian cultural aspect) and thus can be wasted and invested. In cultures where time is perceived as controllable factor, people tend to be punctual, agendaoriented and monochromic. Business practices such as schedules, planning, appointments for meetings and taking responsibility for late delivery of products and services are parts and parcels of the corporate management culture. In cultures where time is considered as something to do with the nature or environment, people (Mexican, Pakistani cultural aspect) tend to be less punctual and polychromic (Macan, 1994; Taylor and Mackenzie, 1986). The way people perceive the time factor, it will influence the way individuals control their time. In monochromic time-oriented cultures, individual employees establish goals and plan accordingly to increase job performance and job satisfaction. Time management impacts every aspect of an individual's life including work life, family life, social and private life (Macan, 1994; Taylor and Mackenzie, 1986).

High versus low power distance: This national cultural dimension measures the degree of acceptance or rejection of the unequal distribution of power and influence in organizations. The power and influence include distribution of knowledge, wealth, resource, information, authority, and the relationship between the boss and subordinates. In low power distance societies (U.S. cultural aspect), individuals feel equal to their peers (especially to superiors or subordinates). In high power distance societies (Mexican, Russian, Pakistani cultural aspect) individuals feel unequal to their peers (superiors or subordinates) (Hofstede, 1997; Hofstede, 1993).

Individualism versus collectivism: This cultural dimension measures the degree of how 
much individuals in a society care about themselves versus care about others. Individualistic societies (U.S. cultural aspect) tend to be more self-oriented where individual performance leads to individual outcomes. Individual independency and interests are protected and promoted. In contrast, collectivist cultures (Mexican, Pakistani, Russian cultural aspect) are group oriented where interdependency and group interests override individual interests. Individuals are accountable to social norms and individual performance is measured by social standards (Hofstede, 1997; Hofstede, 1993).

Masculinity versus femininity: This dimension measures the degree of how much (high/low) individuals in a culture are motivated by competition, personal achievement and success. Individuals in masculine societies (U.S. cultural aspect) tend to prefer individual competition, achievement and success, whereas individuals in feminine societies (Russian cultural aspect) tend to care for others and want quality life for all (Hofstede, 1997; Hofstede, 1993).

High versus low uncertainty avoidance: This dimension of national culture measures the degree of how much individuals in a society risk when making decisions or taking action in an uncertain situation. Individuals from societies where uncertainty avoidance is high (Mexican, Pakistani, Russian cultural aspect) are considered not adventurous and risk-takers in decision making. Such individuals may need more time, information, planning and support before they make any decisions about the future. Contrastingly, individuals from societies where uncertainty avoidance is low (U.S: cultural aspect) tend to be high-risk takers when making decisions about the future (Hofstede, 1997; Hofstede, 1993).

Indulgence vs. restraint is defined as the extent to which people try to control their desires and impulses. Indulgence stands for a society that allows relatively free gratification of basic and natural human drives related to enjoying life and having fun. Restraint stands for a society that suppresses gratification of needs and regulates it by means of strict social norms. The Restrained nature of Russian culture is visible through a tendency to cynicism and pessimism. In contrast, indulgent societies (Mexican, U.S. cultural aspect) put much emphasis on leisure time and joy.
The US, Mexican, Pakistani and Russian National Culture

The US National Culture: The American national culture is recognized as being individualistic, freedom oriented and competitive (Cook, 2012). Americans value equality, informality and individual privacy. American people are generally hardworking, disciplined, action and achievement oriented. They are also direct, assertive and largely materialistic (Cook, 2012). Personal progress, egalitarianism and self-control are other values of American people (Althen, Doran and Szmania, 2003) both in social and professional life. Individual responsibility, decisiveness, strong work ethic and forceful determination to have success in life are fundamentals for the American people (Brown, 1973; Nord et al., 1976; Gallant, 2013). American people are generally future oriented and tend to work hard to make future better and successful. Consumerism and materialism are accepted. The nature can be controlled and should be controlled by planning and controlling resources to serve better the humankind (Bjorn, 1999). Time is key factor in success since time is money, time can be wasted and invested. Efficiency, skills and logical approach to solving business problems are common characteristics or American business managers (Bjorn, 1999). American people are highly task oriented and profit focused. Workers are viewed as hardworking individuals. They can make their own decisions, and control their own lives and environment (Bjorn, 1999). Americans accept changes and risks for the betterment of the self and the society at large. American culture is also viewed by external (non-American) observers as being selfish, greedy (Bjorn, 1999), aggressive and arrogant. In general, in accordance with the Hofstede's dimensions of national cultures, Americans are found to be low in the power distance index; high individualistic; high in masculinity and low uncertainty avoiding.

Mexican National Culture: The Mexican national culture is characterized as paternalistic culture in which high power distance and group orientation are accepted and practiced. Mexican managers make most of the strategic decisions leaving little or no control for operational staff to make decisions (Shimoni and Bergmann, 2006). Managers resolve conflicts, establish goals and measure the outcomes using established standards and criteria but without involving employees or subordinates in the 
lower hierarchy (Nicholls et al., 1999). Mexican companies are managed like family units in which the owners and managers (mostly managers are the owners) act like father figures for the general employees in expectation to gain respect and loyalty (Nicholls et al., 1999). Studies (e.g., Kras 1989; Kras, 1994) find that Mexicans tend to be highly class-sensitive, fatalistic minded, and collectivist at the same time. Mexicans consider both religious values (majority are Roman Catholics) and spending good life essential in one's life. Mexicans work to live, spend time with friends, like hobbies and sports. Macho attitudes are prominently demonstrated by Mexican men (Gomez, 1993). As mentioned earlier, Mexican national culture is generally group-oriented. Individual members of the group therefore, are expected to maintain group harmony and conform to social norms of the group. Strong interpersonal relationships and building trust are critically important for future business relationships. While doing business in Mexico, friendliness, goodwill and respect are keys for the success in the long run. Mexicans do business with individuals not with companies, so the process of establishing business or working relationships may take time (Davis and Nayebpour, 2004). Making and maintaining friends whether social or professional are helpful in solving both social and business conflicts in Mexico. Family status, connections and education are respected (Kras, 1989; Kras, 1994). Other key personal features such as sincerity, integrity, charisma, and sociability are highly valuable. Communication is polite and diplomatic since confrontational and conflictive approach to resolve differences are not functional (Katz, 2006). Overall, according to Hofstede's dimensions of national cultures, Mexico is considered: A hierarchical society where power, class and status are recognized and valued; a collectivistic society promoting long-term commitment, loyalty, social relationships and group affiliations; a masculine society where managers are expected to make decisions, to be decisive and assertive; and, a high uncertainty avoiding culture where risks are not taken and managers would not make risky and adventurous decisions. Decisions require time, information, consultation and approval from the competent authorizes in the hierarchy (Davis and Nayebpour, 2004; Morris and Pavett, 1992).

Pakistan National Culture: The national culture of Pakistan is described as collectivist, status-conscious and having a large power distance (Jamal, 1998; Khilji, 2001). The social set up is family centered and life is built within a group (Lyon, 1993). People keep a strong need for security and disapprove of independence in decision making and questioning authority (Khiliji, 2004). In general, a business culture in Pakistan is based on personal relationship and business is conducted among friends. If the business is negotiated between two Pakistani companies a lot of inter-personal negotiations have already been conducted in a social setting before the question enters the boardroom. The eldest, the head of the concern, will make his decision with or without you though he will politely listen to your views (Khiliji, 2004; Anjum, Zia, Shamsi and Aziz, 2013). If the business is conducted with a foreign company, a lot of lobbying should be done already before actually negotiating the issue. Friendship should be formed and confidence built. The formal meetings are only held to formalize the deal (Khiliji, 2004). The British influence on Pakistani culture is believed to have created social class system, notably feudal and civil servants. The elite symbolize money, power and status. The education system in Pakistan also requires surrendering to authority-personal initiatives, and originality and independence in decision making are met with disapproval (Khilji, 2003). Pakistani managers tend to make rational decisions, they are dependent, and try to avoid spontaneous decision-making which characterize them as high-risk averse and favorites of high power balance between boss and subordinates (Rehman, 2010; Khilji, 2001). Pakistani social infrastructure is built around joint family system (Baloch, Ali, Ahsan and Mufty, 2010) and organization cultures reflect bureaucratic structure, authoritarian management and centralized decision making styles. Decisions relating to employee management such as promotion, pay increase, and training and development are made based on personal likes and dislikes. Managers and owners tend to focus on their own profit while ignoring the interests or welfare of the employees (Baloch, Ali Ahsan and Mufty, 2010; Syed, 1995). Pakistan is considered a collectivistic society where long-term commitment and loyalty are critically important as a member of society or an organization. When it comes to the issue of whether the Pakistani society is masculine or feminine, the general understanding supports the notion that 
Pakistani culture tend to be masculine than feminine. Generally, the Pakistani culture promotes uncertainty avoidance where managers in corporations follow rigid rules and regulations, planning, punctuality and security (Rehman, 2010; Khilji, 2001; Waseem, 1994; Syed, 1995).

Russian National Culture: The Russian Federation, commonly known as Russia, is a transcontinental country extended over much of Northern Asia and Europe. The largest country in the world by land area is characterized by the national culture notably different from European or Asian cultures (Bollinger 1994, Ledeneva 2001). Russian mentality seems to be closer to the cultures of Portugal, Mexico and Brazil (Kirsanov A.,2013).

Russia is characterized as a collectivistic country as evidenced by Hofstede's (IND 39, https://geert-hofstede.com/russia.html)

estimates. The Russian perception of the value of the group lies in the group's ability to provide protection to the members of the group (Naumov and Petrovskaja, 2008, p.6). However, the members of the group may hold individualistic values, not being ready to sacrifice own interests for the interests of the group, but ready to comply with the norms of group behavior (Naumov and Petrovskaja, 2008, p. 6).

The roots of Russian collectivism trace back to the cultural traditions of the Slavic tribal society and The Russian Orthodox Church. Biological, economic and social survival of everybody and of the whole group in the many historical epochs depended upon strong group cohesion and discipline. The social roots of collectivism may be found in the system of "zadruga" - a clan or extended family commune, "the mir" - an agricultural village commune, "the artel" workers' cooperatives, and the Soviet "kollektiv" time. The Russian Orthodox Church encouraged strong family ties, and inter-group mutual assistance. A high level of individual freedom was not supported inside the society, and there were quite a few limitations to expressing individual competitiveness. Collectivism can be considered as the explanation of a lot of phenomena and attitudes of people, such as "wait and hope for a protection from the chief", low personal responsibility for solving problems and so on.

Russia is thought to be a country with femininity (MAS 36) orientation (Hofstede,
1980), however in early post-perestroika period there was some shift toward masculinity (55), but in 2006 the index of masculinity dropped to 48. It indicates some comeback to the traditional Russian values: cooperation, mutual understanding, and interpersonal relations.

Another important thing for understanding Russian corporate culture through national culture is the dimension of power distance (PD index is 93 in 1980, 40 in 2000, and 33 in 2006). The fall relates to increasing influence of Western management model within organizations. Nevertheless, most people still agree that the manager should be the most powerful and authoritarian. Russian business is characterized by hierarchy based on power separation. The boss of the organization is the main source of the ethical norm of the organization; the subordinates prefer not to argue with him and do not criticize his behavior and decisions. Managers often demonstrate paternalism toward the subordinates who have a restricted choice of behavior alternatives. Thus, subordinates' behaviors mostly reflect the ethical view of the boss.

Another important cultural dimension is uncertainty avoidance (the index is 95 in 1980, 68 in 2000 and 70 in 2006). Like many other cultures with high uncertainty avoidance the need for a lot of rules and regulations is connected mostly with emotions and thus these rules are not always clear, consistent and applicable. In combination with high power distance it means that usually people stick to rules when they are expected to be checked or controlled. In business, it leads to the requirement to prepare a lot of paperwork, stamps and signatures, not all of them you need because they are necessary but because of the rules and regulations stipulating so. On the other hand, uncertain environment at the end of 1990 -ies and the beginning of $21^{\text {st }}$ century with lots of changing situations made a lot of people, especially businesspeople, quickly and creatively adjust to new conditions in the environment. They demonstrate specific traits needed for quick reaction, multi-scenario thinking, networking and sharing risk.

Long term orientation was decreasing in modern Russia; this dimension scores 81 in 1980, 59 in 1996 and 62 in 2006. People and business do not tend to save and collect material resources because all the savings and capital can be lost due to a lot of reasons. 
Specific feature of the modern Russian business mentality is the fact that they do not consider the business as something eternal, sustained, and transmitted from parent to children and grandchildren everyday work; business is supposed to be an opportunity to capture, gain the profit quickly and hide it from the state (Korsakov, 2013). The reasons are connected both with the history of the state and the legal and financial context of the country. There is a shortage of long-term planning, long money, credits and investments. At the same time, business is extremely relation oriented and making and maintaining long term personal relations is a high priority for business people. Many new Russian entrepreneurs work successfully in networks, and they often prefer relying on friendship and social interaction rather than formal agreements.

\section{Comparative Analysis of the Four National Cultures}

Culture and organization are two concepts that, without a doubt, are interrelated. Sometimes running a new business in another country, entrepreneurs pay little attention to such important aspect as national culture or do not pay it at all. They are used to managing their company and people using such rules and norms as they are used to having in their home country. But each country differs from another and has its own rules and behavior norms.

Table 2 provides an interesting comparison of the four countries based on the variables collected from the existing literatures. In Mexico, more than $90 \%$ of the population is Catholic and people practice religious functions with respect and punctuality. Similarly, in Pakistan 97\% of the population is Muslim and people are very religious. Russia belongs to Christian Orthodox belief. All of them, Orthodox, Catholic and Islam provide its believers with certainty (avoidance of uncertainty is high) and masculine values tend to prevail in Catholic and Islamic countries (Hofstede, 1997). Social organization is centered in family where father and mother play important roles. Russian, Spanish (national language of Mexico) and Urdu (national language of Pakistan) are high context languages which means, in all three languages indirectness, implicitness and non-verbal language is high. When dealing with business contracts, Russians, Mexicans and Pakistanis view the business relationship as a long-term deal and tend to trust the person not the company. In terms of approach to time management such as deadlines, schedules, planning and time controlling, Mexican and Pakistani cultures have relaxed sense of time. Not because time is not important but because time controlling is not within the scope and authority of the man in these two cultures. Russian, Mexican and Pakistan societies are collectivist societies where individuals belong to family, neighborhood and the society at large (Greer and Stephens, 1996; Khilji, 2004). Pakistani culture is considered a traditionalist culture where values reflect family, class, the past and revealed truth. Leadership is autocratic, male head of family as model. Women's status is generally low and time urgency is unimportant (McFarlin and Sweeny, 1998). In Mexican cultural system, one can find the same features of family, class, male head of the family (Machismo) and time and urgency are unimportant. The same we can conclude about the Russian traditional roles. Traditional cultures are usually strong in uncertainty avoidance, high in power distance, and tend to associative thinking (McFarlin and Sweeny, 1998). Similarly, Mexican, Russian and Pakistani cultures are grouped as particularistic where good relations with family and friends are vital. Importance of interpersonal relationship is high, institutionalized obligations are to family and friends, main basis for rewarding employees is employee's personal situations and purpose of pay raise is to stimulate better performance. Rules and standards should be adjusted depending on the subordinate or situation (McFarlin and Sweeny, 1998). In Mexican organizations, as in Pakistan and Russian organizations, workers feel that conformity, respect, and personal loyalty to supervisors are important and should be rewarded. Honoring status is part of Mexican business rituals. Lewis (1996) groups India, Pakistan, Arab countries and Latin American countries as multi-active which means impatient, emotional, unpunctual, people oriented, talkative, seeks favors and delegates to relations. Mexico, Russia and Pakistan are found to be in the group of high power index cultures. Such cultures accept inequality as the cultural norm and these cultures therefore are vertical. People respect hierarchy and authority and formalized rituals (Dodd, 1998).

Interestingly, Mexican, Russian and Pakistani national cultures are closely related to each 
other based on most of the cultural variables used in this study. However, the American culture is different from these countries except masculinity tendency. Mexico, Pakistan and USA, all three countries reflect masculine tendencies in their respective societies showing the impacts of globalization and corporate cultures on societies. American society tends to promote and appreciate individualism, high time orientation, equality and risk taking attitude. Though Christianity (various branches) has strong roots in America and so does the Protestant work ethics, Americans tend to separate religious beliefs from professional life and thus religious beliefs are very personal matters. Families in America are organized around nuclear family setup where parents and children are the primary members of the family. The American language English is a low context language when comparing with Urdu and Spanish (Bjorn, 1999; Cook, 2012; Althen, Doran and Szmania, 2003; Doran and Littrell, 2012).

Table 2. National Cultures: Mexico, Pakistan, the USA and Russia

\begin{tabular}{|l|l|l|l|l|}
\hline Variables & Mexico & Pakistan & USA & Russia \\
\hline Religion & Catholics & Muslims & Protestants & Christian Orthodox \\
\hline $\begin{array}{l}\text { Social } \\
\text { organization }\end{array}$ & $\begin{array}{l}\text { Extended family } \\
\text { centered }\end{array}$ & $\begin{array}{l}\text { Extended family } \\
\text { centered }\end{array}$ & $\begin{array}{l}\text { Nuclear family } \\
\text { Centered }\end{array}$ & $\begin{array}{l}\text { Extended family } \\
\text { centered }\end{array}$ \\
\hline Language & Mid-high context & High context & Low & Mid context \\
\hline Time concept & Relative & Relative & Absolute & Relative \\
\hline $\begin{array}{l}\text { High/low power } \\
\text { distance }\end{array}$ & $\begin{array}{l}\text { High power } \\
\text { distance }\end{array}$ & $\begin{array}{l}\text { High power } \\
\text { distance }\end{array}$ & $\begin{array}{l}\text { Low power } \\
\text { distance }\end{array}$ & $\begin{array}{l}\text { High power } \\
\text { distance }\end{array}$ \\
\hline $\begin{array}{l}\text { Individualism vs } \\
\text { collectivism }\end{array}$ & Collectivist & Collectivist & Individualistic & Collectivist \\
\hline $\begin{array}{l}\text { Masculinity vs. } \\
\text { femininity }\end{array}$ & Masculine & Masculine & Masculine & Femininity \\
\hline $\begin{array}{l}\text { Uncertain } \\
\text { avoidance }\end{array}$ & $\begin{array}{l}\text { High uncertainty } \\
\text { avoidance }\end{array}$ & $\begin{array}{l}\text { High uncertainty } \\
\text { avoidance }\end{array}$ & $\begin{array}{l}\text { Low } \\
\text { uncertainty } \\
\text { Avoidance }\end{array}$ & $\begin{array}{l}\text { High uncertainty } \\
\text { avoidance }\end{array}$ \\
\hline
\end{tabular}

\section{Corporate Management Culture}

Management in the organization context may be broadly defined as getting things done through other people. Managers make decisions, allocate resources, and direct the activities of others to attain goals. Corporations are business organizations and management is about the process and people involved in that process (Hofstede, 1993). Though certain management practices are universally applicable, some other management aspects vary from culture to culture (Culpan and Kucukemiroglu, 1993; Pheng and Yuquan, 2002). Having said that it is important for business corporations entering alliances with organizations beyond their national boarders to understand and take into account the differences found in management practices across national cultures since the business operations are increasingly becoming global (Hofstede and Bond, 1991). Corporate management styles are influenced by various organizational variables such as values, norms, ethical codes, rules and regulations for example, and such variables vary across national cultures. Cultural variables do influence managerial functions, roles and responsibilities (Laurent, 1983; Mead, 1998). Management style is about how managers behave and function when dealing with employees inside the company. Management style is the set of principles by which managers capitalize on the abilities of their employees (Schleh, 1977). Some management cultures accept and promote the work culture where managers are responsible for organizing, planning, coordinating, decision making and they have the authority and control over organizational resources. Whereas, some other cultures emphasize on the notion that employees should be treated well, managers 
should delegate authority and resources to their employees and managers are coaches and mentors (McGregor, 1960; Ouchi, 1981; Brozik, 1994). In summary, the organizational culture is composed of variables such as management style, decision making process, staffing procedures, interpersonal trust and confidence, commitment, control, importance of relationship, team work and role of nature (Greer and Stephens, 1996; Johnson and Sholes, 2007). Organizational culture also includes the power structure, organizational structure, functional policies and management systems (Johnson and Sholes, 2007; Heller and Yulk, 1969; Goodale, 1973). Organizational cultures are influenced by the external culture such as industry and nation (Gordon and DeForrest, 1994). Organization culture is about the values, rules, practices and norms through which organizations manage their business operations (Brache, 2002; Schien, 1985; Schien, 1995). A strong and dynamic organizational cultural system is fundamental for the organizational competitive advantage, if such cultural system is learned, developed and shared across the global organizational system (Titieve, 1959; Kanungo and Mendonca, 1994; Farmer, 2005).

Given the fact that corporate management culture involves a set of diverse and complex variables, in this paper, a few but key variables of corporate management cultures are briefly elaborated in the following section.

General Management Style: Management style can be classified in two broader categories. Managers can be autocratic and democratic. Autocratic managers do not delegate authority to their subordinates. They will make most of the strategic and operational decisions. They will also control assets and resources within their jurisdiction. On the other hand, democratic managers will delegate authority to their subordinates in terms of decision making and resource management (McGregor, 1960; Schleh, 1977; Ouchi, 1981; Brozik, 1994).

Decision Making Process: Decisions of strategic and operational nature can be centralized versus decentralized. In centralized decision-making setup, managers in charge will make all or most of the decisions and transfer those decisions down to the lower staff in the chain of command for implementation. Lower staff in the hierarchy will not have therefore, options of giving opinion and questioning the decisions already made by the person in-charge of the department or company. In a decentralized decision making system, decision making process will involve individual concerns and participation. Virtually, everybody will be consulted before the final decision is made. Of course, the final decision should be approved by the person in-charge. In contrast to the centralized decision making system, in decentralized decision making setup, decisions of operational nature can be made by the lower staff in the event of necessity and urgency (McGregor, 1960; Schleh, 1977; Ouchi, 1981; Brozik, 1994).

Staffing: Staffing means hiring people in organizations. Some organizations in some cultures use criteria for staff selection such as academic preparation, experience and other specialized skills. These selection criteria are called technical criteria. Contrastingly, in some other cultures organizations use selection criteria such as affiliation of the person with the company, family, political connection and age for staffing purposes. These criteria of staffing are considered staffing based on social characteristics (McGregor, 1960; Schleh, 1977; Ouchi, 1981; Brozik, 1994).

Controlling: The term controlling describes the process of regulating organizational activities so that actual performance conforms to expected organizational standards and goals (Deresky, 1998). Controlling is an ongoing management function requiring managers to set up systems and produce desired behavior to facilitate the achievement of the company's goals. Controlling employee behavior in the workplace could be exercises either by social actions or by technical means. Social actions include appreciating employee performance, showing concern for the employee and his/her family, recognizing his/her efforts and developing personal rapport. Technical means of controlling employee behavior involve formal reporting relationship, budgeting, rewards and punishment, objectives achievement evaluation and regular supervisor. Which of these controlling mechanisms is appropriate and effective in a specific situation is a cultural question (McGregor, 1960; Schleh, 1977; Ouchi, 1981; Brozik, 1994).

Time Concept: Time is a valuable and limited resource to be saved, scheduled and spent with precision. Deadlines and schedules should be met. Some cultures view time based on religious beliefs and destiny (Deresky, 1998). Cultures 
which consider time as an absolute concept are called monochromic time oriented cultures, and cultures where time is viewed as a relative concept are considered polychromic time oriented cultures. Monochronics believe that accomplishments and tasks can be divided into segments and each segment should be performed at a time. Polychronics attempt to do several things simultaneously in a non-linear sequence (Dodd, 1998). Time is increasingly viewed as a factor that organizations must manage. Our conception of time is strongly affected by culture because time is an idea rather an object (Trompenaars and Turner, 1998).

Employee Motivation: The term motivation refers to an individual's choice of behaviors and the impetus behind those behaviors (Deresky, 1998). Managers are responsible to set up a situation in which individual desires to carry out certain activities that will lead to the achievement of organizational goal (Deresky, 1998). Existing research works suggest that motivation tools are more likely to be social, interpersonal and spiritual (Budhawar, 2001). Motivation is influenced by the context of an individual's personal work and personal life and that context is greatly influenced by cultural variables, which affect the attitudes and behaviors of individual and groups on the job (Deresky, 1998). Motivation is cultural. In some cultures, workers can be motivated by team work, the need for the job, relation with their peers, flexible work hours and relaxed work standards. In other cultures, people will be motivated by personal goals, division of labor, specific rules and opportunities for individual advancement (Deresky, 1998).

Role of Religion in the Workplace: Natural environment has been at the center of discussion for researchers as source of human existence. Natural elements such as floods, winds, earthquakes, famine, cold, fire and so and so forth have surrounded human being from the inception (Trompenaars and Turner, 1998). Societies conduct business with two major orientations of nature: either to control and subdue the nature by imposing will upon it or man is part of the nature and must go along with its laws, directions and forces (Trompenaars and Turner, 1998). Who controls the nature? Some cultures believe that it is the man with knowledge and resources who controls the nature. It is just like that which happens to me is because of my actions. Some other cultures believe that the nature is controlled by other forces other than man itself such as God. That is why man has no control over it and therefore, must go along with it (Trompenaars and Turner, 1998).

\section{National and Corporate Management Cultures: A Comparative Analysis}

Several studies (i.e., Horii et al, 2005) undertaken to understand the relationship between corporate management and national cultures find that management practices and national cultures congruency lead to the better organizational performance. Similarly, Hofstede (1991) proposed that each culture has a preferred coordination mechanism, implying that workers from each nation deliver a better performance if they use their own preferred management practices. Similarly, Newman and Nollen (1996) find that business performance is better when management practices match with the national culture since national differences influence management styles (Pheng and Yuquan, 2002). Management styles are deeply influenced by the social culture in which the organizations operate (Prodip, 1995).

General Management Style: In Mexico managers are autocratic and paternalistic. Mexicans value status and accept hierarchy. Workers expect respectful recognition of their roles within the hierarchy. Employees hesitate to provide decision making input or assume decision making responsibilities and risks (Kras, 1994; Ghosn and Ries, 2005). Generally, subordinate do not challenge a decision made by supervisor or superior. Pakistan culture is also considered to be autocratic and paternalistic (Shaw, 1998).

Russian management is characterized by high power distance and paternalism as the two countries considered above. It means that the ruling body of the company counts on the special rights and privileges between them and their subordinates. In most of the Russian companies there are many hierarchical levels in the organization culture and more often topmanagers have an authoritarian style of management. Also, there is more centralized decision-making and a significantly differential wage. In Russia, there is a high level of uncertainty avoidance, therefore organizations would tend to have more formalization evident in a greater number of written rules and procedures, and managers are motivated by 
stability and security. Russian managers prefer group decision-making to avoid blame, which shows high uncertainty avoidance. In contrast, the American culture is characterized by shortterm employment, individual decision-making, individual responsibility rapid evaluation and promotion, explicit, formalized control, specialized career paths and segmented concern (Ouchi and Jaeger, 1978).

Decision Making Process: In Mexican companies the authority to make decision lies with the top in the hierarchy. Decisions are centralized and undemocratic. Roles are clearly separated between boss and subordinate. The boss makes decision and the workers should support the decision without making judgment about the decision. Usually, managers will not delegate authority to their employees to make decisions of their own. Also, the authoritarian management style of the Mexican managers tends to discourage upward communication (Kras, 1994). In Pakistani organizations, since managers are autocratic, decision making process is controlled and centralized on the top. Decisions are generally made by the high ups in the rank and transmitted down to the junior levels through hierarchical channel (Shaw, 1998). Rational and dependent decision makings are preferred styles of Russian managers. Interesting to note that in Russian, Pakistani and Mexican organizations, decisions even of important and strategic nature can be made orally and disseminated among the staff. On occasions employees may be encouraged to contribute ideas and suggestions, but they will not be given authority to make decisions. Decision making is centralized and the final decisions in these countries lie in the hands of the managers in top positions. The American culture is characterized by individual decisionmaking, individual responsibility and managers delegating authority and responsibilities (Ouchi and Jaeger, 1978).

Staffing: In any organization and for any position, in Mexico, Russia and Pakistan, while hiring employees, nepotism and favoritism are generally practiced. In hiring, relationship and connection are decisive criteria more than technical competences of the candidate. Since in Mexico, Russia and Pakistan, loyalty to superior is important, such staffing custom helps hiring employees who can be trusted (Shaw, 1998; Kras, 1994). The American culture in which individual productivity and efficiency are the sources of organizational effectiveness, staff practices such as short-term employment, rapid evaluation and promotion, staffing mostly on academic backgrounds, specialization and experience, and specialized career paths (Ouchi and Jaeger, 1978). When selecting among job applicants, Mexican employers typically look for a work history that demonstrates ability to work harmoniously with others and to cooperate with authority. They also tend to seek workers who are agreeable, respectful and obedient rather than innovative and independent (DeForest, 1994).

Control: Mexican, Russian and Pakistan workers accept authority, power distance, status and role identification (Kras, 1994; Shaw, 1998). Following instructions, rules and standards are minimal in both cultures. However, Mexicans workers would prefer more social mechanisms (i.e., friendship, trust) to control them since they do not like formal (technical) controls (i.e., rules, standards). Mexican worker will usually do the work as favor not his or her duty as a job; he will do it for personal relationship and maintain his image among the workers (Kras, 1994). In American culture control is accepted and practiced through procedures, standards and other explicit and formalized control mechanisms such as management objectives and performance based evaluation and promotions (Ouchi and Jaeger, 1978). Mexicans, Russian, Pakistani tend to be comfortable with inequalities of authority whereas Americans prefer sharing authority with peers and bosses in the workplace (Marchese, 2001; Jiméneza, Faschib and Valdezc, 2009).

Time Management: In Mexico and Pakistan time is an uncontrollable factor which is controlled by nature not by human being. For an ordinary Pakistani, time has no concept and therefore, getting things done on time is quite impossible (Khiliji, 2004). However, because of the historical background (British legacy in Pakistan), Pakistani workers and young office employees will tend to be on time always to the work. Managers may exercise flexibility in their time management. Assignments can be accomplished in the last minutes. Appointments may not be considered as commitments in some parts of the country (Shaw, 1998). Being late for an appointment shows that the person is a boss. His esteem rises. Yet, punctuality is expected of foreigners (Khiliji, 2004). Since Pakistan has several sub-cultures, approach to time management may vary from state to state or even from city to city within a state. In Mexico, 
generally, time is a relative concept and a Mexican worker cannot be expected always to be on time. For Russians, the value of time is "elastic": being late is not perceived as being rude, deadlines are flexible, Russian management does not fit easily in "westernized" practices of time management, planning is not rigorous, issues and problems are solved under pressure and stress at the last-minute. American punctuality, time management and planning are universally known and appreciated. For Americans, time is money and time can be invested and wasted.

Employee Motivation: Mexico, Russia and Pakistan are developing economies where the importance of monetary benefits to meet the basic needs is high. Therefore, job related satisfaction is given priority over other human needs such affiliation and esteem. Though some findings suggest that motivation in Pakistan may require the provision of affiliative needs and social recognition, it can be associated with the type of profession (Shaw, 1998). In American culture, where masculinity, consumerism, and social class is based on ownership (money, properties), good salaries and other tangible economic/financial benefits can be a useful source of motivating and keeping employees motivated.

Role of Religion in the Workplace: Islam as religion of the $95 \%$ of the population in Pakistan has a strong role in organizational culture in comparison with the Catholic influence in the Mexican organizational culture. Mexicans are considered religious in belief and refer to God for everything they do in life as Muslims do, however, since the separation of church from the government, Mexicans are found to be relatively less conservative in practice. Any company in Pakistan whether of foreign origin or national has to allocate a prayer room where employee can say their prayers during office hours, extend lunch breaks for Friday prayers and shorter office hours during Ramadan, the month of fasting (Khiliji, 2001; Kazmi, 2005). Such religious practices and rituals are very rare to found in companies located in Mexico or Russia regardless of their origin and nationalities. In the USA, people keep secular views of religion and being religious is something very personal. Having said that, the American Protestant work ethics, which promotes productivity, hard-work, commitment, and effective time management, has dominated the global work culture.

Table 3, summarizes the differences and similarities among the corporate management cultures of the three countries under investigation:

Table 3. Comparative Analysis of Management Cultures: Pakistan, Mexico and USA

\begin{tabular}{|c|c|c|c|c|}
\hline Variables & Mexico & Pakistan & USA & Russia \\
\hline $\begin{array}{l}\text { Management } \\
\text { Style }\end{array}$ & $\begin{array}{l}\text { Autocratic and } \\
\text { paternalistic }\end{array}$ & Autocratic & Pragmatic & $\begin{array}{l}\text { Autocratic and } \\
\text { paternalistic }\end{array}$ \\
\hline $\begin{array}{l}\text { Decision } \\
\text { making process }\end{array}$ & $\begin{array}{l}\text { Centralized and } \\
\text { individualized }\end{array}$ & $\begin{array}{l}\text { Centralized and } \\
\text { individualized }\end{array}$ & Consensual & $\begin{array}{l}\text { Centralized and } \\
\text { individualized }\end{array}$ \\
\hline $\begin{array}{l}\text { Staffing } \\
\text { procedures }\end{array}$ & $\begin{array}{l}\text { Connections, } \\
\text { references }\end{array}$ & $\begin{array}{l}\text { Connections, } \\
\text { references }\end{array}$ & $\begin{array}{l}\text { Merit and } \\
\text { Achievement }\end{array}$ & $\begin{array}{l}\text { Connections, } \\
\text { references }\end{array}$ \\
\hline Control & $\begin{array}{l}\text { Social control is } \\
\text { accepted }\end{array}$ & $\begin{array}{l}\text { Technical } \\
\text { control is } \\
\text { accepted }\end{array}$ & $\begin{array}{l}\text { Technical control is } \\
\text { accepted }\end{array}$ & $\begin{array}{l}\text { Technical } \\
\text { control is } \\
\text { accepted }\end{array}$ \\
\hline $\begin{array}{l}\text { Time } \\
\text { management }\end{array}$ & Less punctual & $\begin{array}{l}\text { Punctuality } \\
\text { varies }\end{array}$ & $\begin{array}{l}\text { Punctuality at all } \\
\text { cost }\end{array}$ & $\begin{array}{l}\text { Punctuality } \\
\text { varies }\end{array}$ \\
\hline $\begin{array}{l}\text { Role of religion } \\
\text { at workplace }\end{array}$ & $\begin{array}{l}\text { Exists but not } \\
\text { strong }\end{array}$ & Very strong & None existence & None existence \\
\hline $\begin{array}{l}\text { Motivation } \\
\text { strategies }\end{array}$ & $\begin{array}{l}\text { Social recognition } \\
\text { and } \\
\text { economic benefits }\end{array}$ & $\begin{array}{l}\text { Social } \\
\text { recognition and } \\
\text { economic } \\
\text { benefits }\end{array}$ & $\begin{array}{l}\text { Economic benefits } \\
\text { and social } \\
\text { recognition }\end{array}$ & $\begin{array}{l}\text { Social } \\
\text { recognition and } \\
\text { economic } \\
\text { benefits }\end{array}$ \\
\hline
\end{tabular}




\section{DISCUSSION AND CONCLUSION}

The four countries under analysis in this paper inherit rich and diverse cultural and historical backgrounds. America (USA) is considered a melting pot as a cultural system because of its cultural diversity and being an immigrant society. The historical influence of British, Spanish and French cultures in combination with the mass mobilization of people from Asia, Africa and Latin America have led to the conclusion that America's culture is everybody's culture (Morrison, 2006; Moran, Harris and Moran, 2010). The Mexican culture as well has passed through various de-culturation and acculturation eras initiating with Aztecs and Mayan kings to the era of Spanish empire and French invasion. In spite of these historical events and occurrences, and the fact that America, the most influential nation in the world is its neighbor, Mexico has been able to keep its identity intact as a Latin American culture (Gomez, 1993; Kras, 1994; Noll, 1992).

Russia is a meeting of Europe and Asia, and the cultural portrait reflects this. Russian culture grew from that of the East Slavs, with their pagan beliefs and specific way of life in the wooded areas of Eastern Europe. Early Russian culture was much influenced by neighboring Finno-Ugric tribes and by the nomadic peoples of the Pontic steppe. In the late 1st millennium $\mathrm{AD}$ the Scandinavian Vikings also took part in the forming of Russian identity and the Kiev Rus' state. Orthodox Christian missionaries began arriving from the Eastern Roman Empire in the 9th century; this largely defined the Russian culture of the next millennium as the synthesis of Slavic and Byzantine cultures. After the fall of Constantinople in 1453, Russia remained the largest Orthodox nation in the world. At different points in its history, the country was also strongly influenced by the culture of Western Europe. Since the reforms of Peter the Great, for two centuries Russian culture largely developed in the general context of European culture rather than pursuing its own unique ways. The situation changed in the 20th century, when the Communist ideology became a major factor in the culture of the Soviet Union, where Russia was the largest and leading part. Nowadays, Russian cultural heritage is a mix of different influences that created a modern country profile. It is a collectivist society, where members prefer working as a group with interdependence, an emotional connection to the group, and a desire for group harmony. Russian collectivism is described as a horizontal collectivism. Orthodox beliefs de-emphasize independence and selfreliance in thinking. In terms of Russia's political dominance, it has normally been under authoritarian rule. The interdependence found in Russian culture reflects to norm of "being" as opposed to "doing". "Doing" cultures assess value by how much people accomplish while "being" cultures are more concerned about their relationships and tend to live for the moment and take life as it comes. Russia is said to be more collectivist, desires a large power distance and has high uncertainty avoidance.

The Pakistani culture has seen even more complex and diverse intrusions in its history dated back to the invasion of Alexander the great; the Mongols, the Moghuls; the Persian; and the British a few to narrate. Since its arrival in early $8^{\text {th }}$ century, Islam has been the dominant religion in the region but the influence of many other religions including Buddhism and Hinduism can be observed in some parts of Pakistan (Khilji, 2003; Khilji, 2001; Khilji, 2004).

While comparing these four national and corporate cultures it is found that American organizations are well organized and hierarchies are established to facilitate the operations. Employees' and managers' relationships are based on equality and achieving organizational objectives. Information sharing, consultation and participating decision making are common practices in the U.S. (American) organizations. Employees are expected to be self-reliant. The system of hiring, promoting and decision making are based purely on merits and expertise. The American society is self-achievement and interpersonal competition driven. Americans live to work and therefore, monetary benefits and rewards leading to higher social status are successful motivation strategies in American companies. Americans like changes and accept innovative ideas and practices. The American society promotes self-sufficiency, independency and individualism which consequently influence the American companies to be less autocratic and more flexible with employees having control over operational level decision making and supervision (Jiméneza, Faschib and Valdezc, 2009).

The Mexican society is hierarchical and social classes and unequal power distribution is 
accepted. Consequently, in Mexican organizations authority is concentrated in the top management, no delegation of authority and decisions are centralized (Teegen and Doh, 2002). Pakistani and Russian organizations are typically authoritarian as well and decision making is located at the top due to large power distance. Employee autonomy is limited, topbottom communication is minimal and bottom up communication is non-common (Khilji, 2004). Organizational structures are bureaucratic and not generally responsive to the needs of employees. Existing theories also suggest that creative management is limited by rigid rules and regulations and thus individual initiatives and contributions are non-existence in Pakistan organizations whether they are public or private (Quershi, 1995; Khilji, 2001).

The organizational culture in Mexico, Russia and Pakistan tend to be person oriented (Trompenaars and Turner, 1998) since in these countries authority is a figure head, paternalistic and powerful. Motivations are generally intrinsic, personal respect is more important than monetary benefits. Otherwise, these cultures are considered as a family culture where close to close but hierarchical relationship exists. This is in the sense that the father of a family has experience and authority greatly exceeding those of his children. This is power oriented organizational culture in which the head is regarded as a caring father who knows better than his subordinates what should be done and what is good for them. In such organizational culture the pressure is social and moral than financial or legal. In contrast to the Russian, Pakistani and Mexican cultures, the American culture tend to be more transaction (job, task) oriented which lead to create organizational cultures of productivity, selfcontrol, responsibility and independency among the workers.

Overall social organization (the importance of family), the spirituality (the importance of religion) and the external influence are relatively similar when comparing Mexico, Russia and Pakistan. But the American reflects a clear distinction from these samples. Pakistani national culture is an amalgamation of Islamic religion, Indian origins, British inheritance and American influence (Khilji, 2001). Similarly, Mexican national culture is a combination of the Catholic religion, Spanish heritage, American influence and the indigenous origin. In general, Mexican, Pakistani and Russian national value systems based on community, group life, strong need for dependency, respect for the authority, dominance of elite class in social and political life, culture of broken promises and poor human development record. All three of these cultures are collectivist and high power distance cultures (Khilji, 2001; Nicholls et. al., 1999). According to Hosfstede's four national dimensions, Russia, Pakistan and Mexico are considerably similar and are in the same group of countries with large power distance-collectivist dimensions (Hofstede, 1997).

In conclusion, commonness in the national value systems of Mexico, Pakistan and Russia, three geographically distanced but socioculturally close nations have a significant effect on the value systems of the organizations. This presents several opportunities for the organizations in these countries. Organizations in different sectors such as oil and gas, textile, education, consulting, research and development can make up strategic alliances to pursue international business ambitions. Also, companies from Mexico can make direct investment in the Pakistani or Russian market and similarly companies from Pakistan and Russia can do business in Mexico without fearing of the cross-cultural constraints.

\section{IMPLICATIONS AND RECOMMENDATIONS}

The finding of this study presents implications for the corporate leaders in many ways: (1) Even though the Mexican, Pakistani and Russian cultures are found to have vivid similarities, these nations are located far from each other geographically (the distance). Mexico is geographically close to the USA but culturally very far from it. Pakistan is far from the USA both geographically and culturally. Russia is geographically remote from USA, Mexico and Pakistan but has cultural similarities with Mexico and Pakistan (2) Spanish, Urdu, Russian languages are in the group of high context languages in the world of communication, but still they are different languages. Managers from both sides must learn some language to communicate and understand the culture better. English is a low context language, but it has become a generic and common business and management language globally; (3) Despite the fact of cultural closeness of Mexico, Russia and Pakistan, there are huge differences in Catholicism, Christian Orthodox and Islam faithroots, as well as when it comes to the practice of 
religion and the importance given to the religion in one's daily life. (4) Social organization is formed around extended family infrastructure in Pakistan as in Mexico or Russia whereas the US social organization is much more decentralized to nuclear family establishment. Corporate leaders from the USA can have tough time while working with employees from either Mexico, Russia or Pakistan; (5) Other variables of power distance, uncertainty avoidance, collectivism/ individualism, masculinity/femininity and time concept used in this study and the effects of these variables on corporate management cultures suggest that Mexicans, Russians and Pakistanis tend to be more similar than different. Though, being Latin American versus South Asian cultures, the realities on ground can present challenges for managers from both side.

Given all those implications described above, managers and investors from these four countries are advised to take national cultures as well as organizational culture into account when developing national and organizational business polices and standards. Managers and investors from these countries know the world is becoming a global place and the need for cross cultural learning is increasing with the growth of business organizations beyond their national borders (Qamar, Muneer, Jusoh and Idris, 2013). Individuals bring cultures of origin to work that reflect their ongoing histories in various cultural contexts, such as national culture (Gibson and Zellmer-Bruhn, 2001; Hofstede, 1980). In this manner, culture guides our choices, commitments, and standards of behavior (Erez and Earley, 1993). Corporate managers are global and should understand differences in global cultural system. They should be able to work on those differences and adopt managerial practices which are culturally sensitive and responsive (Erez, 2000).

\section{LIMITATIONS IN THE STUDY AND FUTURE STUDIES}

This study is based on the conceptual analysis of the causal relationship between the national cultural variables and the corporate management culture variables. Such studies are considered research problem explorers and theory ground-breaker therefore, are viewed useful for further studies in the field. Exploratory studies such as this one establish the context for further quantitative analysis, identify needs for the research, broaden the knowledge of the researcher and clarify the existing theories in the field of study (i.e., Aitchison, 1998; Leedy, 1989; Bless and HigsonSmith, 2000). However, such research endeavors are viewed descriptive, general and are criticized for not presenting field data, statistical analysis and other quantitative procedures to establish the relationship among the research variables. Research quality can be influenced by the researcher personal experience, rigor is more difficult to achieve and findings are difficult to understand (American Association of Colleges of Pharmacy, 2010). Moreover, some researchers question the validity and reliability of the findings of such studies since the information is obtained through document analysis and secondary sources. This demands from the researcher to scrutinize and critically evaluate the source or the origin of the information used in the study.

Therefore, future studies in the field should consider several considerations. First, studies should not only analyze the relationship of correlations or causal relationships between the research variables, but also and most importantly to give weight to the moderating and mediating variables. Figure 2 demonstrates that there several emerging variables (factors) that can have powerful moderating roles in establishing the relationship between the dependent (Corporate Management Culture) and independent (National Culture) variables in this study. For example, Figure 2 suggests that variables such as information technologies, globalization, internationalization of HRM, business strategic alliances, workforce diversity and regionalization, may have moderating impacts on how national cultural variables can influence the corporate management cultures. To expand the research scope and strengthen the generalization of the results, a few more dependent variables (employee motivation, management orientation, work ethics and loyalty) could be added to the study and analysis. 
National culture

- Religion

- Social organization

- Language

- Time concept

- Power distance

- Individualism

- Masculinity

- Uncertainty avoidance

on

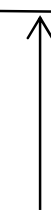

Moderating forces

- Information technologies

- Globalization of corporations

- Internationalization of HRM

- Business alliances

- Workforce diversity

- Regionalization
Corporate management culture

- General management style

- Decision making styles

- Staffing mentality

- Controlling mechanisms

- Time management

- Employee motivation

- Role of religion in the workplace

- Management orientation

- Work ethics

- Loyalty

Fig 2. The Role of Moderating Variables

In terms of the research methodology used in the study, future studies should use quantitative methods to make the study outcomes more understandable and acceptable in the scientific research community. The quantitative method also enhances the validity and reliability of the research results and consequently the recommendations. Qualitative studies as this one are generally appreciated for being explanatory, detailed and in-depth. Also, changes in the direction of the study is easier as new information emerges and data/information collected based on human observations is more powerful than the quantitative data (Anderson, 2010). On the other side, qualitative studies being dependent on the researcher skills, thus can be easily influenced by the researcher personal biases. It is time consuming and difficult to assess and communicate (Anderson, 2010). A more formal and field-based study involving business organizations from four countries should be built to explore the reality on the ground. This paper is surely a step forward in that direction. Also, future studies should consider adding interview results from managers from each country to update and support the review done in the paper. Interview results can be generated from individual interview or focus groups of supervisor/subordinate from each country stated in this research. This qualitative research is a very important step prior to go further to conclude the factors affecting organizational culture in general.

\section{REFERENCES}

Anwar, S. A., and Chaker, M. N. (2003), Globalization of corporate America and its implications for management styles in an Arabian cultural context. International Journal of Management, 20 (1): 43-56.

Anjum, M., Zia, S. M., Shamsi, A. F., and Aziz, A. (2013), The Impact of Culture on the Perception of Employees and Organizational Productivity in Pharmaceutical Industries in Karachi. Global Management Journal for Academic \& Corporate Studies, 03(01).

Ahmad, S., and Owoyemi, M. Y. (2012), The Concept of Islamic Work Ethic: An Analysis of Some Salient Points in the Prophetic Tradition. International Journal of Business and Social Science, 3(20).

Aitchison, J. (1998), Access to books and journal articles by post-graduate students on a course-work master's program in information studies at the University of Natal, Pietermaritzburg. MIS Thesis, University of Natal, Pietermaritzburg.

Ali, A., and Al-Shakis, M. (1985), Managerial value systems for working in Saudi Arabia: An empirical investigation. Group and Organization Studies, 10(2): 135-152.

Althen, G., Doran, A. R., and Szmania, S. J. (2003), American Ways: A Guide for Foreigners in the United States, $2^{\text {nd }}$ ed. Boston: Intercultural Press.

Alvesson, M. (2002), Understanding Organizational Culture. Sage Publications, London.

Asvin S. (2000), Impact of Soviet Gender Order 
on Modern Situation in the Employment Sphere. Sociological Research, No. 11 (64)

Anderson, C. (2010), Presenting and Evaluating Qualitative Research. American Journal of Pharmaceutical Education 74(8): 1-7. Retrieved from http://www.medscape.com/viewarticle/73 1165_3

Au, K. Y. (1999), Intra-Cultural Variation: Evidence and Implications for International Business. Journal of International Business Studies, 30: 799812.

Balan, S., and Vreja, L. O. (2013), The Trompenaars' seven-dimension cultural model and cultural orientations of Romanian students in management. Proceedings of the 7th International Management Conference "New Management for the New Economy", November 7th-8th, Bucharest, Romania.

Baloch Q.B., Ali, N., Ahsan, A., and Mufty, A. (2010), Relationship between HR practices and perceived employees' performance of bankers in NWFP, Pakistan: empirical evidence. European Journal of Social Sciences, 10(2): 210-214.

Banks, R. (1998), The Protestant Work Ethic. Faith in Business Quarterly, 2(2): 5-7.

Bing, J. W. (2004). Hofstede's consequences: The impact of his work on consulting and business practices. Academy of Management Executive, 18 (1), retrieved from http://www.itapintl.com/aboutus/articles/hofstedes-consequences

Bjorn, B. (1999), Business leadership and culture: National management styles in the global economy. Cheltenham, UK: Edward Elgar.

Bless, C. and Higson-Smith, C. (2000). Fundamentals of social research: An African perspective. 3 rd edition. Cape Town: Juta.

Bollinger, D. (1994), The Four Cornerstones and Three Pillars in the "House of Russia" Management System. Journal of Management Development, 13(2), 49

Brache, A.P. (2002), How organizations work. John Wiley \& Sons, Inc, New York, NY.

Brown, J. D. 1973, The Human Nature of Organizations. New York: USA. Amacom.

Brozik, D. (1994), The second dimensions for successful management. Manage, 45(4), 48.

Budhwar, P. (2001), HRM in India, in P. Budhwar and D. Ya (eds) HRM in Developing Countries, pp. 75-90. London.

Cook, G. (2012), The Influence of National Culture on American Business peoplemanagerial Implications for Central Europe. Central European Business Review Research Papers, 1(2).

Culpan, R., and Kucukemiroglu, O. (1993), A Comparison of U.S. and Japanese Management Styles and Unit Effectiveness. Management International Review, 33(1): 27-42.

Davis, A. S., and Nayebpour M. R. (2004), Obreros (Workers) Against Gerentes (Managers): Changing Values in the Mexican Workplace. Latin American Business Review, 5(1): 71-93.

DeForest, M., (1994), Thinking of a Plant in Mexico. Academy of Management Executive, 8 (1): 33-40.

Deresky, H. (1998), International Management: Managing Across Borders and Cultures. Addison-Wesley, 2nd edition, 1998.

Dodd, H. C. (1998), Dynamics of Intercultural Communication. Fifth Edition. McGrawHill. USA.

Doran, C. J. and Littrell, R. F. (2012), Measuring Mainstream US Cultural Values Received: 26 September 2012 /Accepted: 27 September 2012 / Published online: 14 October 2012 Springer Science+Business Media Dordrecht 2012.

Erez, M. (2000), Make Management Practice fit the National Culture. In: Locke, E.A. (Ed.), pp. 418-434, Basic Principles of Organizational Behavior: A Handbook. NY: Blackwell.

Erez, M., and Earley, P. C. (1993), Culture, Selfidentity, and Work, New York, Oxford University Press.

Farmer, R. T. (2005). Corporate Culture Defines a Company and its Future. American Journal of Business, 20(2):7-3.

Franke, R. H., Hofstede, G., and Bond, M. H. (1991), Cultural roots of economic performance: A research note. Strategic Management Journal, 12: 165-173.

Furnham, A. (1990), Language and personality. In H. Giles and W. Robinson, editors, 
Handbook of Language and Social Psychology, pages 73-95. Wi-ley, Chichester.

Gallan, M. (2013), The Business of Culture: How Culture Affects Management Around the World. Retrieved from http://www.halogensoftware.com/blog/th e-business-of-culture-how-cultureaffects-management-around-the-world

Gannon, M. J, (1980), Understanding Global Cultures, Sage, Thousand Oaks.

Gannon, M. J. and Associates. (1994), Understanding global cultures: Metaphorical journeys through 17 countries. CA: Sage Publication.

Georgas, J. (2003), Family: Variations and changes across cultures. In W. J. Lonner, D. L. Dinnel, S. A. Hayes, \& D. N. Sattler (Eds.), Online Readings in Psychology and Culture (Unit 13, Chapter 3), Center for Cross-Cultural Research, Western Washington University, Bellingham, Washington USA.

Ghaemawat, P., and Reiche, S. (2011), Globalization Note Series, National Cultural Differences and Multinational Business, Globalization Note Series.

Ghosn, C., and Ries, P. (2005). Shift: Inside Nissan's Historic Revival. New York: Doubleday.

Gibson, C. B., and Zellmer-Bruhn, M. E. (2001), Metaphors and meaning: An intercultural analysis of the concept of teamwork. Administrative Science Quarterly, 46(2): 274-303.

Gomez, E. J. (1993), Mexican Corporate Culture: Modernization in Managerial Methods. Business Mexico.

Goodale, J. (1973), Effects of Personal Background and Training on Work Values of the hard-core unemployed. Journal of Applied Psychology, 57: 1-9.

Greer, S.K. and Stephens, C. (1996), Employee issues for companies in Mexico. California Management Review, 38(3): 121-145.

Hall, E. T. (1976), Beyond Culture. Garden City, NY; Anchor Books.

Hassan, M. K. (1988), Pendidikan dan pembangunan Bersepadu. Kuala Lumpur: Nurin Enterprise.

Heller, F.A., and Yukl, G. (1969), Participation, managerial decision-making and situational variables. Organizational

Behavior and Human Performance, 4: 227-241.

Hickson, D. and Pugh, D. (2002), Management Worldwide. London: Penguin.

Hofstede, G. (1980), Culture's Consequences. Sage Publication, London.

Hofstede, G. (1983), The Cultural Relativity of Organizational Practices and Theories. Journal of International Business Studies, 14(2):75-89.

Hofstede, G. (1991), Cultures and Organizations. McGraw-Hill, London.

Hofstede, G. (1993), Cultural constraints in management theories. The Executive, 7(1): 81-95.

Hofstede, G. (1997), Cultures and Organizations: Software of the Mind-Intercultural Cooperation and its Importance for Survival. McGraw-Hill, UK.

Hofstede, G. (2001), Culture's Consequences: Comparing, Values, Behaviours, Institutions, and Organizations across Nations. Sage Publication, London.

Hofstede, G. (2007), Asian management in the 21st century. Asia Pacific J Manage, 24: 411-420.

Hofstede, G., and Bond, M. H. (1988), The Confucius connection: From cultural roots to economic Growth. Organizational Dynamics, 16(4): 4-21.

Hofstede, G., Hofstede G. J., and Minkov M., (2010). Cultures and Organizations: Software of the Mind. Revised and Expanded 3rd Edition. New York: McGraw-Hill USA

Hooker, J. (2008), Cultural Differences in Business Communication. Tepper School of Business, Carnegie Mellon University.

House, R. J., Hanges, P., Javidan, M., Dorfmann, P., and Gupta, V. (2004), Culture, Leadership and Organizations: The GLOBE Study of 62 Nations, Thousand Oaks, CA: Sage.

Jamal, A. (1998), Can We Learn Something from the Perceptions and Consumption Practices of Transnational South Asian Communities Living in the West? Paper presented at the Inaugural Conference of Asia Academic of Management, Hong Kong.

Jimeneza, M. B., Fascib, M. A., and Valdezc, J. 
(2009), A Comparison of Management Style for Mexican Firms in Mexico and the United States. International Journal of Business, 14(3).

Johnson, G., and Scholes, K. (2007). Exploring Corporate Strategy. Financial Times/ Prentice Hall; 8 edition. UK.

Kanungo, R., and Mendonca, M. (1994). Culture and Performance Improvement. Productivity 35(4): 447-53.

Katz, L. (2006), Negotiating International Business - The Negotiator's Reference Guide to 50 Countries Around the World. Publisher: BookSurge Publishing.

Khilji, S. E. (2001), Human Resource Management in Pakistan, in P. Budhwar and D. Yaw (eds.) Human Resource Management in Developing Countries. London.

Khilji, S. E. (2003), To Adapt or Not to Adapt': Exploring the Role of National Culture in HRM-A Study of Pakistan. International Journal of Cross Cultural Management, 3(1): 109.

Khilji, S. E. (2004), Wither Tradition? Evidence of Generational Differences in HR Satisfaction from Pakistan. International Journal of Cross Cultural Management, 4(2):141.

Kluckhohn, F.R., and Strodtbeck, F.L. (1961), Variations in Value Orientations, Evanston, IL: Row, Peterson.

Kirsanov A. (2013), Wild Image, Kommersant.ru, No 103 (5134),18 June 2013. http://www.kommersant.ru/doc/2210199

Kras, E. (1994), Modernizing Mexican Management Styles: With Insights for US companies working in Mexico. Editts Publishing, p. 27.

Kras, E. (1989), Management in Two Cultures: Bridging the Gap Between U.S. and Mexican Managers. Yarmouth, ME: Intercultural Press.

Kras, E., (1989), Management in Two Cultures: Bridging the Gap between U.S. and Mexican Managers, Intercultural Press: Maine.

Kroeber, A., and Kluckhohn, C. (1985), Culture: $A$ Critical Review of Concepts and Definitions. Random House, New York.

Laurent, A. (1983), The cultural diversity of Western conceptions of management.
International studies of management and organization, 13: 75-96.

Leedy, P. (1989), Practical research: Planning and design. 4rth edition. New York: Macmillan.

Ledeneva, A. (2001), Unwritten rules: How Russia really works. London: Centre for European Reform.

Lewis, R. D. (1996), When Cultures Collide: Managing Successfully Across Cultures. Nicholas Brealey Publishing Limited, UK.

Li, J., Lam, J., and Qian, G. (2001), Does Culture Affect Behavior and Performance of Firm? The case of Joint Venture in China. Journal of International Business Studies, 32(1): 115-31.

Lyon, P. (1993), ‘Epilogue’, in P. James (ed.) Pakistan Chronicle. London.

Macan T. H. (1994), Time Management Test of a Process Model. Journal of Applied Psychology, 79(3):38 1-391.

Marchese, M., (2001), Matching Management Practices to National Culture in India, Mexico, Poland, and the U.S. The Academy of Management Executive, 15(2):130-132.

McFarlin, D. B., and Sweeny, P. D. (1998), International Management: Trends, Challenges and Opportunities. SouthWestern College Publishing Company. Ohio.

McGregor, D. (1960), The human side of enterprise. New York: McGraw-Hill.

McKenna, S. (2005), Organizational Commitment in the Small Entrepreneurial Business in Singapore. Cross Cultural Management, 12(2):16.

Mead, R. (1998), International management (2nd ed.). Cambridge, MA: Blackwell Publishers.

Moran, R. T., Harris, P. R., and Moran, S. V. (2010), Managing Cultural Differences, Eighth Edition: Global Leadership Strategies for Cross-Cultural Business Success. Butterworth-Heineman, UK.

Morris, T., and Pavett, C. M. (1992) Management Style and Productivity in Two Cultures. Journal of International Business Studies, 1: 169-179.

Morrison, T. (2006), Kiss, Bow, or Shake Hands: The Bestselling Guide to Doing Business in More Than 60 Countries. Avon, MA: Adams Media. USA. 
Naumov A., Puffer S. (2000), Measuring Russian Culture using Hofstede's Dimensions, Applied Psychology: An International Review, 49 (4), p. 709-718

Naumov A., Petrovskaia I. (2010), Evolution of National Culture Impact on Managing Business in Russia in 1996-2006. Eurasian Review, Vol. 3, November 2010, p.76-87.

Newman, K. L., and Nollen, S. D. (1996), Culture and Congruence: The Fit Between Management Practices and National Culture. Journal of International Business Studies, 27: 753-779.

Nicholas, C. E., Lane, H. W., and Brecha, M. B. (1999), Taking Self-Managed Teams to Mexico. The Academy of Management Executive, 13(3):15.

Nicolaidis, C. S. (1991), Cultural Determinants of Corporate Excellence in an Integrated World Economy: The Impact of National Cultures on Organisational Performance, Reading.

Noll, C. L. (1992), Mexican Macquiladom Workers: An Attitude Toward Working. Journal of Business and Economics, 9(1): 1-7.

Nord, W. E. (1976), Concepts and Controversy in Organizational Behaviour. California Pacific Palisades.

Ouchi, W. G. (1981), Theory Z: How can American business meet the Japanese challenge. Reading, MA: Addison-Wesley.

Ouchi, W.G., and Jaeger, A. M. (1978), Social Structure and Organization. In: Environments and Organizations, Marshall W. Meyer (ed.). San Francisco: Jossey-Bass.

Parsons, T., and Shils, E. A. (1962), Toward A General Theory of Action. New York: Harper and Row.

Parsons, T., and Schwartz, S. H. (1992), Universals in the content and structure of values: Theoretical advances and empirical tests in 20 countries, in M. Zanna (Ed.), Advances in experimental social psychology, pp. 1-65, New York: Academic Press.

Pheng, L. S., and Yuquan, S. (2002), An exploratory study of Hofstede's crosscultural dimensions in construction projects. Management Decision, 40(1): 716.

Pothukuchi, V., Damanpour, F., Choi, J., Chen, C.
C., and Seung, H. P. (2002), National and organizational culture differences and international joint venture performance. Journal of International Business Studies, 33(2): 243-265.

Prodip, K. N. (1995), Management Styles, Tata Mc Graw - Hill Publishing Co. Ltd, New Delhi.

Qamar, A., Muneer, S., Jusoh, A., and Idris, H. (2013). The relationship between organizational conduct and national culture. Journal of Economics and Behavior Studies, 5(2): 82-88. Retrieved from https://www.econbiz.de/Record/therelationship-between-organizationalconduct-and-national-culture-qamarahsan/10009728271.

Qureshi, Z. I. (1995), 'Management in South Asia', in D. MI. Saunders and R. N (eds) New Approaches to Employee Management. JAI Press, Greenwich.

Rajagopal, R., A. (2006), Trust and Cross-Cultural Dissimilarities in Corporate Environment. Team Performance Management, 12(7): 237-252.

Rehman, J. (2010), Analysing the Issue of Cultural and Religious Relativism: With Particular Reference to Muslim Women Rights in South Asia. Study Visit Report to European Commission EURASIA-NET Project.

Rijamampianina, R. (1996), Effective Management in Multicultural Organisations: Creating a Learning-based Order with a Sharing Principle. Economic Journal of Hokkaido University, 25: 119167.

Schein, E. H. (1985), Organizational Culture and Leadership, Jossey-Bass, San Francisco, CA.

Schleh, E. C. (1977), A matter of management style. Management Review, 66(8): 8-14.

Schwartz, S. H. (1999), A theory of cultural values and some implications for work. Applied Psychology: An International Review, 48(1): 23-47.

Shaw, J. (1998), Cultural Variations in Management Practice: An Exploration of the Management. Public Administration \& Development, ABI-INFORM Global pg. 399.

Shimoni, B., and Bergmann, H. (2006), Managing in a Changing World: From Multiculturalism to Hybridization-The 
Production of Hybrid Management Cultures in Israel, Thailand, and Mexico. The Academy of Management Perspectives, 20(3): 76-89.

Slocum, G. K., Williges, B. H., and Roscoe, S. N. (1971), Meaningful shape coding for aircraft switch knobs. Aviation Research Monographs, 1 (3): 27-40.

Steers, R. M., Sanchez-Runde, C. J., and Nardon, L. (2010), Management Across Cultures: Challenges and Strategies. Cambridge University Press

Stephens, G. K., and Greer, C. R. (1995), Doing Business in Mexico: Understanding Cultural Differences. Organizational Dynamics, 24(1): 39-55.

Syed, M. A. (1995), Islam and Democracy in Pakistan, Islamabad, National Institute of historical and Cultural Research.

Tayeb, M. (1994), Organizations and National Culture: Methodology Reconsidered. Organization Studies, 15 (3): 429-46.

Tayeb, M. (1995), The Competitive Advantage of Nations: The Role of HRM and its Sociocultural Context. International Journal of Human Resource Management, 6: 588666.

Taylor, J. and Mackenzie R. A. (1986), Time is money, so use it productively. $A B S A$ Banking Journal, 78: 130-133.

Tylor, E. ikimedia Commons. Popular Science Monthly 26 (1884):14. Public Domain

Teegen, H. J. and Doh, J. P. (2002), US-Mexican Alliance Negotiations: Impact of Culture on Authority, Trust, Performance. Thunderbird International Business Review, 44(6): 749.

Titiev, M. (1958), Introduction to Cultural Anthropology. New York: Henry Holt and Co.

Trompenaars, F. and Turner, C. H. (1998), Riding the Waves of Culture: Understanding Diversity in Global Business. Second Edition. McGraw-Hill, New York.

Trompenaars, F. and Hampden-Turner, C. (1997), Riding the Waves of Culture: Understan Cultural Diversity in Business, Second Edition, London \& Santa Rosa, Nicholas Brealey Publishing Limit.

Tsai, Yafang (2011) Relationship between Organizational Culture, Leadership Behavior and Job Satisfaction, published online

https://www.ncbi.nlm.nih.gov/pmc/article s/PMC3123547

Tylor, E. (1871), Origins of Culture. Harper and Row, New York.

UNESCO (2002), UNESCO Universal Declaration on Cultural Diversity. Retrieved from http://www.unesco.org/education/imld_2 002/unversal_decla.shtml.

Venter P. F. (2004), A Multicultural Approach of consumer time perception. Journal of Consumer Affairs, 12(2):24-33.

Waseem, M. (1994), Politics and State in Pakistan. National Institute of historical and Cultural Research. Islamabad.

Weber, M. (2004), The Protestant Ethic and the Spirit of Capitalism. London: Rutledge.

Weber, Y., Shenkar, O., and Raveh, A. (1996) National and Corporate Culture Fit in Mergers/Acquisitions: An Exploratory Study. Management Science, 42: 12151227.

Willmott, R. (2000), The Place of Culture in Organization Theory: Introducing the Morphogenetic Approach. Organization, 7 (1): 95-128. 


\section{ABOUT THE AUTHORS}

Mohammad Ayub Khan, email: mkhan@itesm.mx

Dr. Mohammad Ayub Khan studied BBA and MBA at the Quaid-e-Azam College of Commerce, University of Peshawar, Pakistan and MBA from Glasgow University, Scotland, UK. While in Mexico, he completed his $\mathrm{PhD}$ in Business Administration, from Trident University International, California, USA. Additionally, he has obtained several other certificates: Certificate of Advanced Manageme-nt, European Summer School, Aarhus Business School, Denmark; English as a Business Language, Monterey Institute of International Studies (MIIS) California, USA; Diploma of Exchange Program for Foreign Students, Tecnológico de Monterrey, Mexico. Dr. Ayub has remained: Director of the International Business Department; Director of the University Honors Program; National Coordinator of International Business Academy at campus Monterrey, Tecnológico de Monterrey, México. He has remained visiting professor teaching international business courses in different universities: Incarnate Word University, Texas USA; Trinity University, Texas, USA; University of Applied Sciences, Bocholt, Germany; Ecole de Superior de Comercio Paris (ESCP-EAP), France. He has also collaborated with the Community of European Management School (CEMS) on a Project of EGADE Business School Mexico \& CEMS Community of European Management School, through Copenhagen Business School, Denmark and University of Boccioni, Milano, Italy. He has co-authored a book titled "THE BASICS OF INTERNATIONAL NEGOTIATION", ISBN 978-3-639-31584-4. www.vdm-vsg.de. $\mathrm{He}$ has published numerous papers on diverse topics of international business and business and management education. Currently he is teaching international business courses at Tecnológico de Monterrey, Mexico.
Dr. Ekaterina Panarina has over 15 years of experience in academic environment in different settings as teaching, running academic and applied research, couching, administrative work, creating, building and growing entrepreneurship and marketing programs including curricular, co-curricular and extra-curricular components. Her diverse skills, qualifications and personal values (integrity, accountability, leadership and teamwork) make her a valuable person to the business education and a scholar work in area of Management, Marketing, Innovation and Entrepreneurship. Her research is mainly in the following areas: Marketing Analysis of Company Environment: Developed Strategy for Maintaining Competitive Market Position; Developed Theory and Application on Increasing Business Competitiveness Nationally and Internationally; Establishing a Center of Competence as a Development Strategy for Competitive Russian Enterprises. Dr. Panarina has more than 45 published articles in research and collaborates along actively with the peers from different countries (as a co-author of the present article for example) in the topics of marketing, entrepreneurship and innovation, and global business. Dr. Panarina is a Marketing Professor of Management and Marketing Department, Business School at Perm National Research Polytechnic University (Russia) and Tecnologico de Monterrey Campus Toluca (Mexico). 